Research paper

\title{
Batiacasphaera bergenensis and Lavradosphaera elongata - New dinoflagellate cyst and acritarch species from the Miocene of the Iceland Sea (ODP Hole 907A)
}

\author{
Michael Schreck ${ }^{\mathrm{a}, *}$, Jens Matthiessen ${ }^{\mathrm{b}}$ \\ ${ }^{a}$ Korea Polar Research Institute, 26 Songdomirae-ro, Yeonsu-gu, Incheon 406-860, Republic of Korea \\ ${ }^{\mathrm{b}}$ Alfred Wegener Institute, Helmholtz Centre for Polar and Marine Research, Am Alten Hafen 26, 27568 Bremerhaven, Germany
}

\section{A R T I C L E I N F O}

\section{Article history:}

Received 18 October 2013

Received in revised form 8 July 2014

Accepted 10 July 2014

Available online 7 August 2014

\section{Keywords:}

Dinoflagellate cyst

Acritarch

Biostratigraphy

Miocene

Iceland Sea

\begin{abstract}
A B S T R A C T
A detailed palynological investigation of the almost continuous middle through upper Miocene sediment sequence of ODP Hole 907A in the Iceland Sea revealed the presence of a new species of the dinoflagellate cyst genus Batiacasphaera, and a new species of the acritarch genus Lavradosphaera. Batiacasphaera bergenensis sp. nov. and Lavradosphaera elongata sp. nov. are both morphologically distinctive and have well-defined stratigraphic range tops that are independently constrained by the pristine paleomagnetic record of Hole 907A. Both species disappeared within a narrow interval across the middle to late Miocene boundary, when smallscale glaciations on Greenland were large enough to reach sea level. The distinct morphology of the proposed species and their highest occurrence in this critical interval highlights their potential for future biostratigraphic application in the Miocene of the high northern latitudes, an area important for understanding the Late Cenozoic transition into a bipolar glaciated world.
\end{abstract}

(c) 2014 Elsevier B.V. All rights reserved.

\section{Introduction}

The high northern latitudes are of crucial importance for global climate due to the Arctic amplification, a process that includes a variety of feedback mechanisms related to the Greenland ice sheet, the formation of perennial/seasonal sea ice cover, and the production of North Atlantic Deep Water (e.g. Serreze and Barry, 2011). It is commonly assumed that the high latitudes also played a decisive role during the Miocene period when Earth's climate was finally pushed into the bipolar glaciated mode of today (e.g. Flower and Kennett, 1994; Zachos et al, 2008). Despite their importance, detailed reconstructions of paleoenvironmental changes that occurred across this period are still seriously hampered by insufficient temporal control on marine sedimentary sequences, primarily due to the rare occurrence of traditionally used calcareous microfossils in these deposits (e.g. Fronval and Jansen, 1996; Matthiessen et al., 2009a). In consequence, organicwalled dinoflagellate cysts (dinocysts) and acritarchs gained increased attention owing to their relatively high abundance and diversity in this realm.

The past decades witnessed significant progress in the application of dinocysts for biostratigraphic correlations and paleoenvironmental reconstructions in the Neogene of the North Atlantic, North Pacific, and the Arctic and subarctic seas (e.g. Bujak and Matsuoka, 1986;

\footnotetext{
* Corresponding author. Tel.: +82 327605388.

E-mail address: Michael.Schreck@kopri.re.kr (M. Schreck).
}

Head et al., 1989a; Manum et al., 1989; De Schepper et al., 2011; Schreck et al., 2012), whereas acritarchs have only been recently recognized as a useful microfossil group to tighten Neogene biostratigraphy in the high northern latitudes (e.g. Matthiessen et al., 2009b; Schreck et al., 2012; De Schepper and Head, 2013; Verhoeven et al., 2013). Notwithstanding, the stratigraphic potential of both groups has not been fully explored yet and numerous Neogene species still remain in open nomenclature to date (e.g. Poulsen et al., 1996; De Schepper and Head, 2013; Schreck et al., 2013). Moreover, Mudie (1989) mentioned uncertainties regarding the equivalence of high northern latitude Neogene taxa reported by different workers as different taxonomic concepts have been applied.

During a detailed palynological investigation on Neogene sediments of Iceland Sea ODP Hole 907A, more than 40 undescribed dinocyst and acritarch taxa have been recognized (Schreck et al., 2013), and two potentially useful new dinocyst species have been described previously (Schreck et al., 2012). Herein we describe a new dinocyst species, Batiacasphaera bergenensis sp. nov., and a new acritarch species, Lavradosphaera elongata sp. nov., which both have well defined stratigraphic range tops in the Iceland Sea. The revised paleomagnetic record of Site 907 (Channell et al., 1999) allows calibration of the ranges to the latest Astronomical Tuned Neogene Time Scale (ATNTS; Hilgen et al., 2012) for independent age control, and we discuss their occurrence in relation to paleoclimatic changes that occurred across the Middle to Late Miocene in the high northern latitudes in order to evaluate their potential for future biostratigraphic application. Given their distinct 
morphology and restricted range, both species may improve biostratigraphic control in the cold-water domain of the Norwegian-Greenland Sea, an area critical for understanding the Late Cenozoic development of Earth's climate.

\section{Material and methods}

ODP Leg 151 Hole 907A was drilled on the eastern Iceland Plateau $\left(69^{\circ} 14.989^{\prime} \mathrm{N}, 12^{\circ} 41.894^{\prime} \mathrm{W}\right.$; $2035.7 \mathrm{~m}$ water depth; Fig. 1$)$, and provides an almost continuous middle through late Miocene sediment sequence that mainly consists of unlithified silty clay and clayey silt (Shipboard Scientific Party, 1995). The revised age model for Site 907 is based on magnetic polarity stratigraphy (Shipboard Scientific Party, 1995; Channell et al., 1999), but is independently supported by four silicoflagellate datums in the Miocene interval (Fig. 2; see Channell et al., 1999; and Schreck et al., 2012 for detailed discussion of the age model). The ages of the polarity chron boundaries given by Channell et al. (1999) have been updated to the ATNTS 2012 (Hilgen et al., 2012), and therefore, this age model allows assigning numerical ages for each sample and bioevent.

Based on the revised magnetostratigraphy of Channell et al. (1999), 120 samples, covering the period from c. 14.5 to $2.5 \mathrm{Ma}$, have been examined for their palynological content on a $\sim 100 \mathrm{ka}$ resolution. Fifteen $\mathrm{cm}^{3}$ sediments were freeze-dried, weighed, and processed using standard palynological techniques (e.g. Wood et al, 1996), including treatment with cold $\mathrm{HCl}(10 \%)$ and cold HF (38-40\%), and sieving over $6 \mu \mathrm{m}$ mesh. The residue has been mounted with glycerine jelly on microscope slides. The results of the detailed palynological investigation are published by Schreck et al. (2012, 2013), and all slides are stored at the Alfred Wegener Institute Helmholtz Centre for Polar and Marine Research, Bremerhaven, Germany. The slides containing all illustrated specimens of Batiacasphaera bergenensis sp. nov. and Lavradosphaera elongata sp. nov. are housed in the Invertebrate Section of the Department of Palaeobiology, Royal Ontario Museum, Toronto, Ontario, Canada, under the catalogue numbers ROM 63053-63054.

For this study, a detailed taxonomic analysis was performed with a Zeiss Axioplan 2 microscope at $100 \times$ magnification. Transmitted light photomicrographs were taken with a ProgRes C5 digital camera. Scanning electron microscopy has been carried out with a Philips XL 30
ESEM at the Marine Geology and Paleontology Department of the Alfred Wegener Institute, Bremerhaven, Germany.

\section{Results and discussion}

This study formally describes a new dinocyst species, Batiacasphaera bergenensis sp. nov., and a new acritarch species, Lavradosphaera elongata sp. nov., from the diverse and moderate to well preserved Miocene palynomorph assemblage of ODP Hole 907A in the Iceland Sea (Fig. 1). The good to moderate preservation of palynomorphs is notably evident among co-occurring protoperidiniacean cysts, e.g. Cristadinium cristatoserratum and Barssidinium graminosum, which are light to dark brown in colour and show no evidence of oxidative damage. The independent magnetostratigraphic age control of ODP Hole 907A (Fig. 2; Channell et al., 1999) allows the calibration of the stratigraphic ranges to the ATNTS 2012 and assesses numerical ages for their highest (HO) and lowest (LO) occurrence as follows (Fig. 3).

In Iceland Sea ODP Hole 907A, Batiacasphaera bergenensis sp. nov. has a total stratigraphic range from the uppermost Langhian (13.68 Ma) into lower Tortonian (11.09 Ma), and both LO and HO are comparatively well constrained by adjacent magnetic polarity reversal boundaries (Figs. 2 and 3). B. bergenensis sp. nov. occurred shortly after the Middle Miocene Climate Transition (MMCT, 14.2-13.7 Ma), during which cooler arctic surface waters likely reached the Iceland Plateau due to the establishment of a protoEast Greenland Current and a ice drift pattern across the Fram Strait similar to today (Jakobsson et al., 2007; Knies and Gaina, 2008; Schreck et al., 2013). It exhibits low abundance (c. $0.3 \%$ of the total dinocyst assemblage) in the lowermost Serravallian, but a significant acme (47\%) occurs at $\sim 13.39$ Ma. This acme coincides with a brief warming in the Iceland Sea and sea surface temperatures (SSTs) of around $20^{\circ} \mathrm{C}$, which are presumably related to the influence of warmer waters branching off the Norwegian-Atlantic Current (Schreck et al., 2013). Temperate conditions likely prevailed on the Iceland Plateau during most of the subsequent Serravallian, but alkenone SSTs show a slight decrease (Schreck et al., 2013) and Batiacasphaera bergenensis sp. nov. occurs only sporadically throughout this interval. However, it is a common constituent $(1-8 \%)$ of the palynomorph assemblages in the lowermost Tortonian again, where its highest occurrence is magnetostratigraphicallycalibrated to 11.09 Ma just below Subchron C5n.2n (Figs. 2 and 3). The range top might be related to the glacial inception in the Iceland Sea as depicted by the onset of predominantly siliciclastic deposition, the

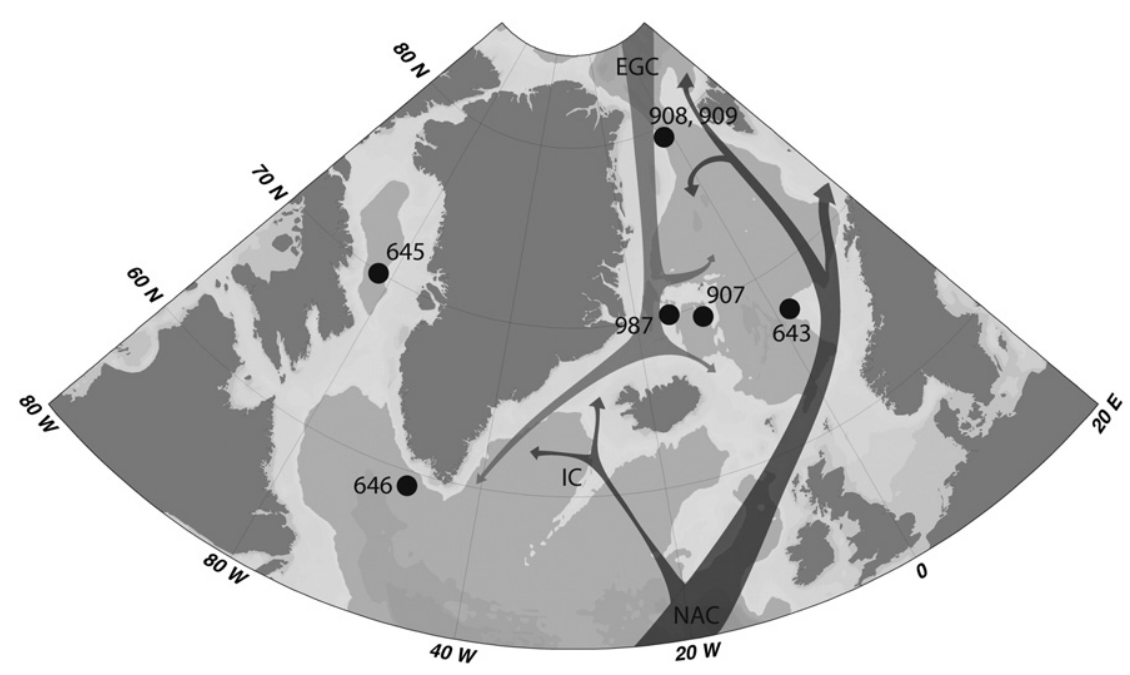

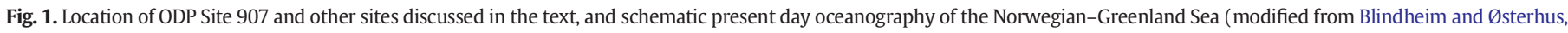

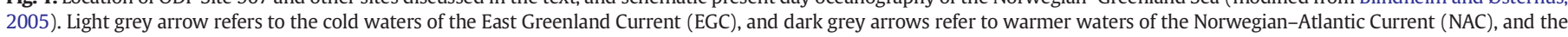
Irminger Current (IC). 


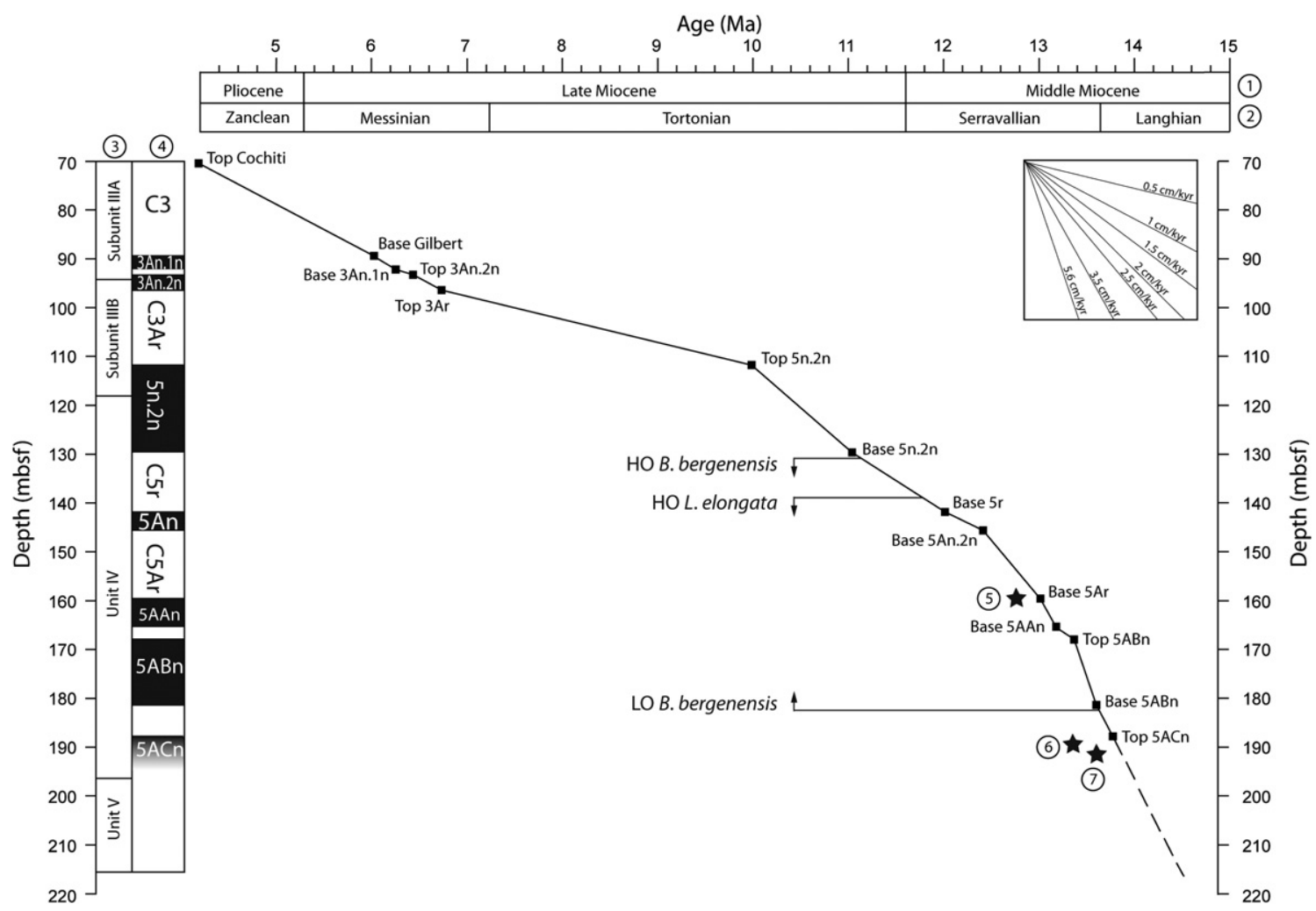

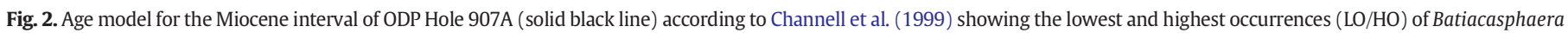

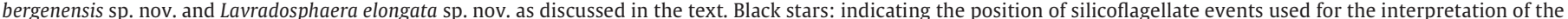

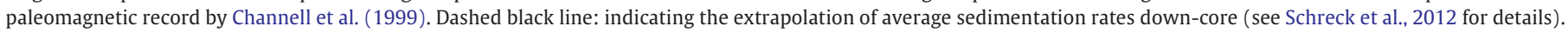

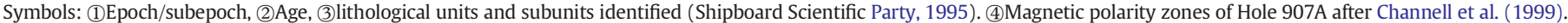

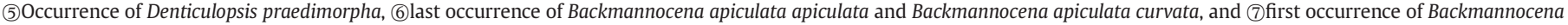
circulus apiculata. All diatom datums according to Amigo (1999).

occurrence of the first drop stone, and the lowest occurrence of the coldwater acritarch Decahedrella martinheadii between 11 and 10 Ma at ODP Site 907 (Shipboard Scientific Party, 1995; Fronval and Jansen, 1996; Schreck et al., 2013). Furthermore, the record of ice-rafted debris (IRD) at other high latitude sites close to Greenland (e.g. Schaeffer and Spiegler, 1986; Fronval and Jansen, 1996; Wolf-Welling et al., 1996; Helland and Holmes, 1997) suggests the establishment of small-scale glaciations on Greenland large enough to reach sea level at around this time. However, based on the stratigraphic occurrence at Site 907 it is difficult to assess the detailed paleoecological affinities of $B$. bergenensis sp. nov., but its acme in the lowermost Serravallian and its disappearance during times of pronounced evidence for cooling suggests a preference for warmtemperate surface waters and/or a sensitivity against cooler conditions. The co-occurrence with abundant Batiacasphaera micropapillata furthermore suggest similar paleoecological preferences (see Schreck and Matthiessen, 2013), but more data on the biogeographic distribution of $B$. bergenensis sp. nov. are needed to further confirm this tentative interpretation.

Lavradosphaera elongata sp. nov. is present in the lowermost sample of ODP Hole 907A (907A-23CC, 10-12 cm; 216.50 mbsf; $14.5 \mathrm{Ma}$ ), thus its LO is not reliably recorded. However, it ranges continuously from the upper Langhian through upper Serravallian (upper Middle Miocene) where its $\mathrm{HO}$ is magnetostratigraphically calibrated to the lower part of Subchron C $5 r$ at $11.81 \mathrm{Ma}$. The record of $L$. elongata sp. nov. from ODP Site 907 therefore represents the oldest documented occurrence of a Lavradosphaera species so far (see De Schepper and Head, 2013). It exhibits highest abundance (up to 30\% of the acritarch assemblage) across the Langhian, but decreases subsequently throughout the Serravallian apparently in concert with the general Neogene cooling that initiated after the MMCT (e.g. Flower and Kenneth, 1994; Zachos et al., 2008). Its well-defined range top coincides with transient minima in palynomorph diversity and concentration in ODP Hole 907A (Schreck et al., 2013), which have been partly attributed to the global cooling during the Mi-5 event (11.8-11.4 Ma, Westerhold et al., 2005). Thus the distribution of L. elongata sp. nov. in ODP Hole 907A suggests a preference for warm-temperate surface waters.

Apart from dinocyst 7 of Manum et al. (1989) from ODP Site 643 in the Norwegian Sea, which we tentatively synonymise with Lavradosphaera elongata sp. nov. (see Systematic palaeontology), both species have only been recorded from ODP Hole 907A to date. This is presumably related to either insufficient drilling depth and/or sample resolution at other suitable sites in the Norwegian-Greenland Sea (e.g. ODP sites 908, 909, and 987), Baffin Bay and Labrador Sea (e.g. ODP sites 645 and 646), and the Central Arctic Ocean (IODP Site M2A). Differences in assemblage composition between the Iceland Sea and North Atlantic sites located just south of the Greenland-Scotland Ridge (Schreck et al., 2013) furthermore suggest that other factors such as temperature, salinity and nutrient availability may contributed to the absence of $B$. bergenensis and $L$. elongata from the mid-latitudes. In addition, the subaerial exposure of the Greenland-Scotland Ridge during most of the Middle Miocene (Denk et al., 2011) and the absence of a modern style East Greenland Current (Sarnthein et al., 2009) likely restricted water mass exchange between the Norwegian-Greenland Sea and the North Atlantic, thus influencing cyst distribution.

The mid-Serravallian to mid-Tortonian interval comprises the middle to late Miocene boundary and is of interest for paleoclimate research as the occurrence of first IRD at several circum-Arctic sites is commonly assumed to reflect glaciations on Greenland large enough to reach sea level (see Thiede at al., 2011 for review), thus denoting the final transition into a bipolar glaciated world. However, in 


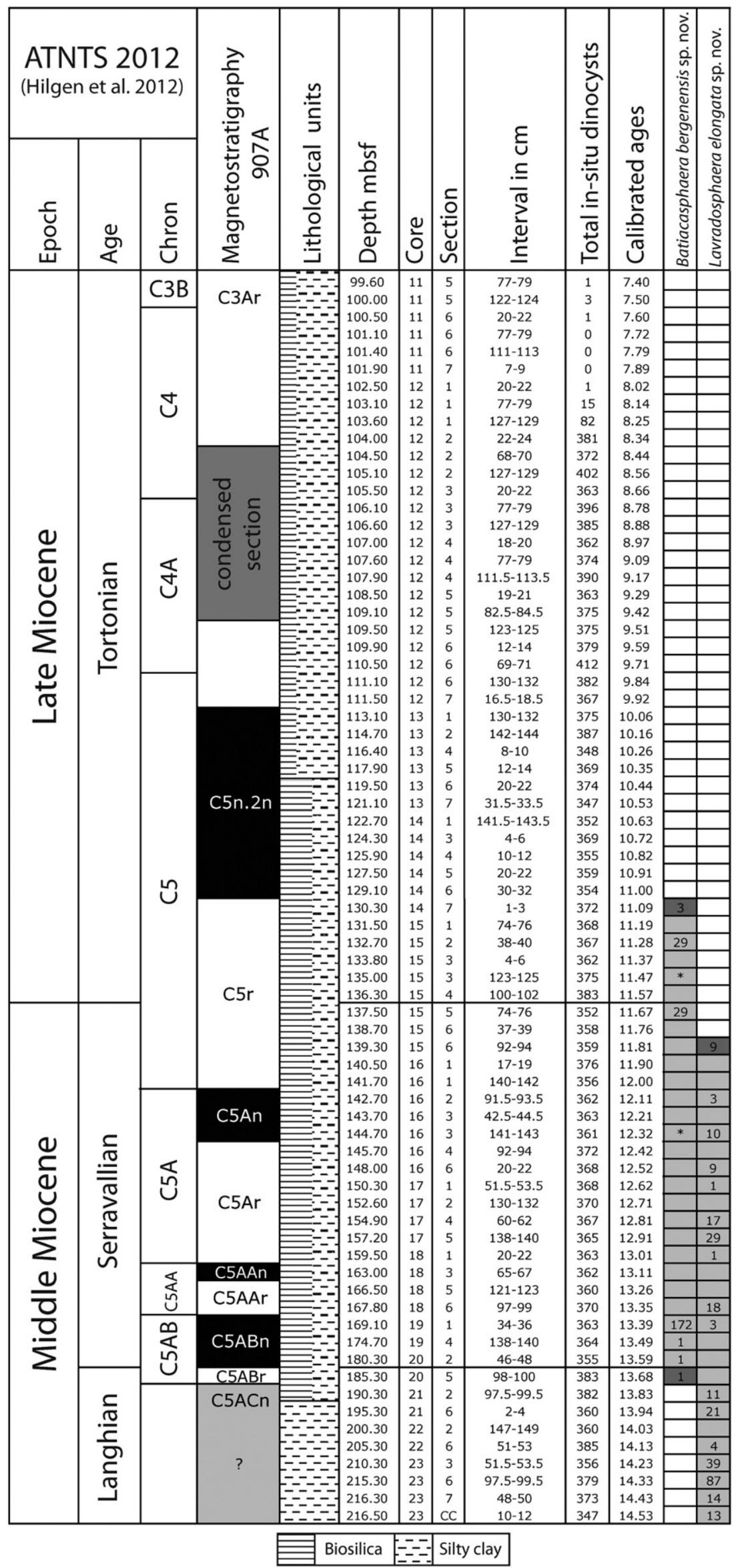




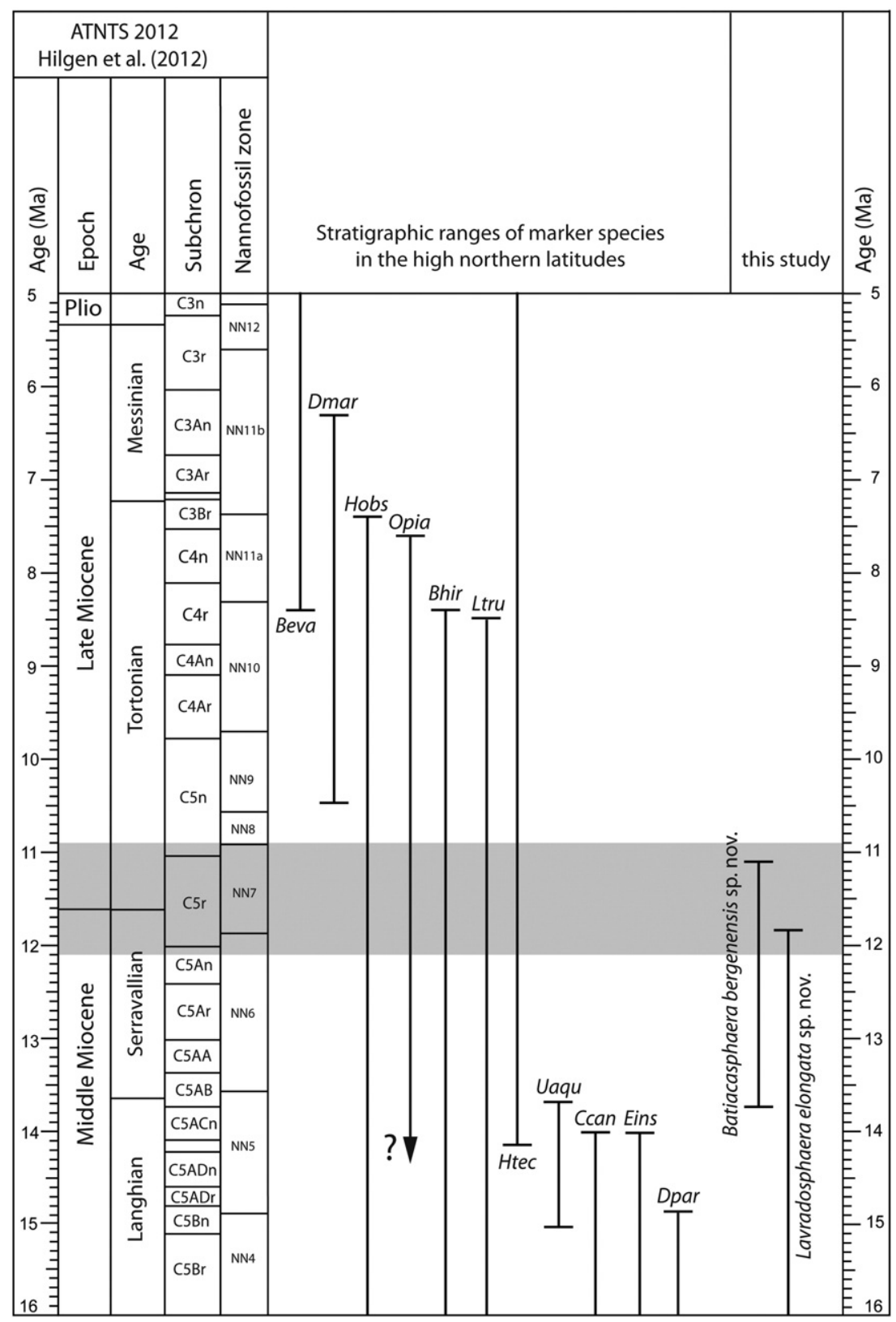

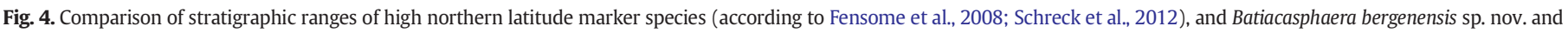

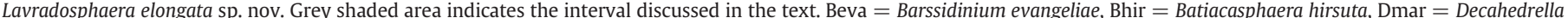

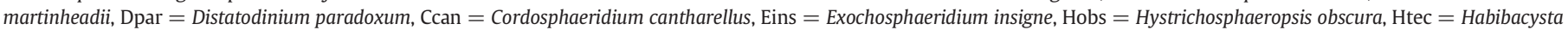
tectata, Ltru = Labyrinthodinium truncatum, Opia = Operculodinium piaseckii, Uaqu = Unipontidinium aquaeductus.

consequence of the fragmentary (palyno)stratigraphic framework (Fig. 4), the exact timing of the Miocene expansion of northern hemisphere ice sheets, which may have played an important role in modulating Neogene climate variability (e.g. Westerhold et al., 2005; De Conto et al., 2008), yet remains subject to uncertainty and debate. As the well-constrained HOs of Batiacasphaera bergenensis sp. nov. and Lavradosphaera elongata sp. nov. are confined to that enigmatic interval (Fig. 4), both species might be of some importance to constrain the Middle to Late Miocene boundary in deposits off East Greenland, and may help to further refine the biostratigraphic framework in order to address the evolution of the Greenland ice sheet in more detail.

\section{Systematic palaeontology}

Division DINOFLAGELLATA (Bütschli, 1885) Fensome et al., 1993 Subdivision DINOKARYOTA Fensome et al., 1993

Class DINOPHYCEAE Pascher, 1914

Subclass PERIDINIPHYCIDAE Fensome et al., 1993

Order GONYAULACALES Taylor, 1980

Suborder UNCERTAIN

Family UNCERTAIN

GenuS BATIACASPHAERA Drugg, 1970

Type Batiacasphaera compta Drugg, 1970 

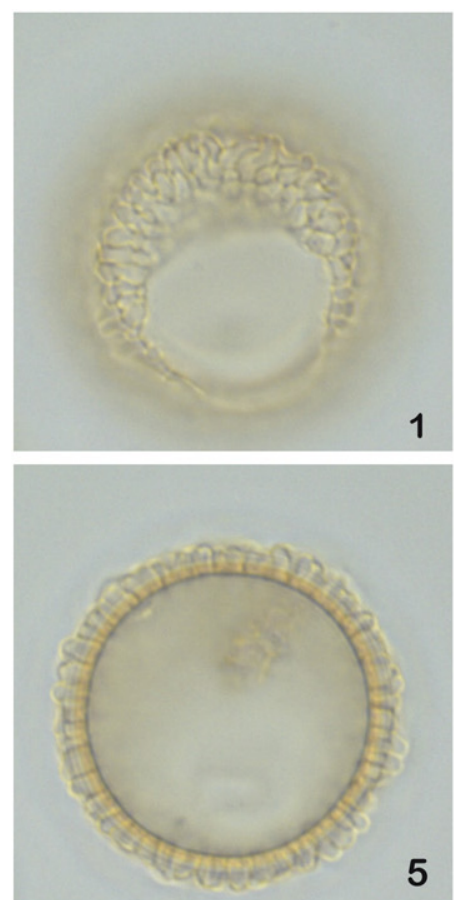

5

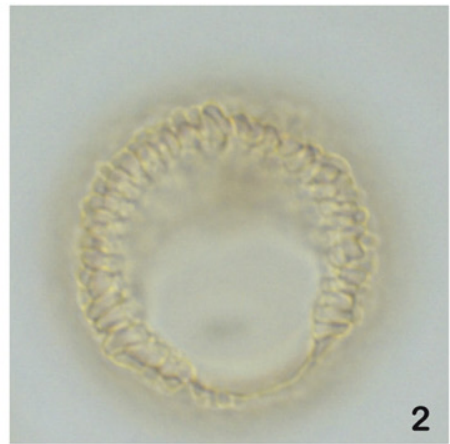

2

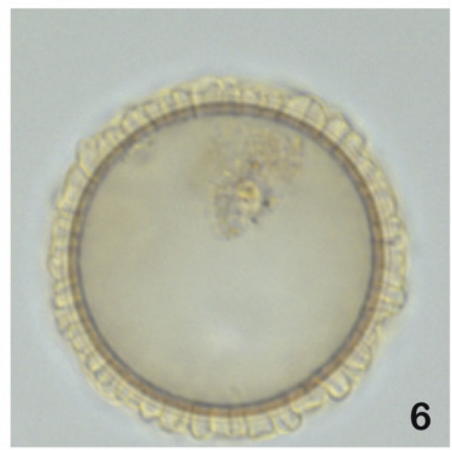

9

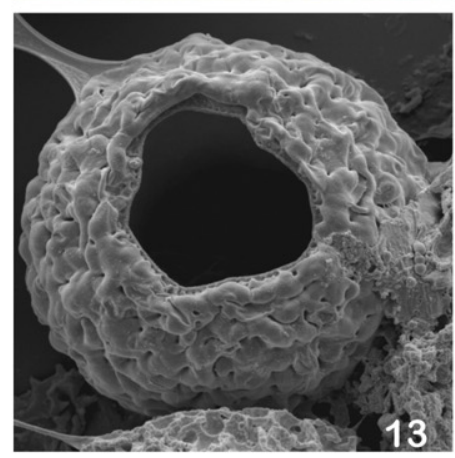

10

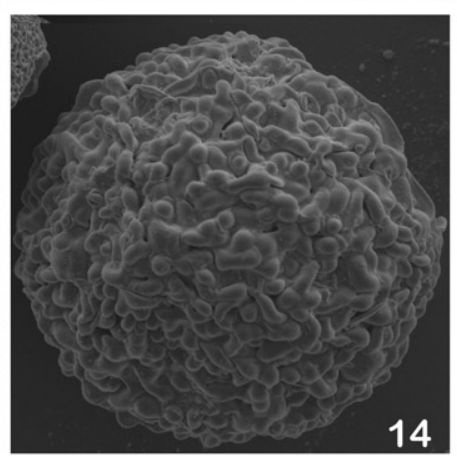

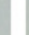

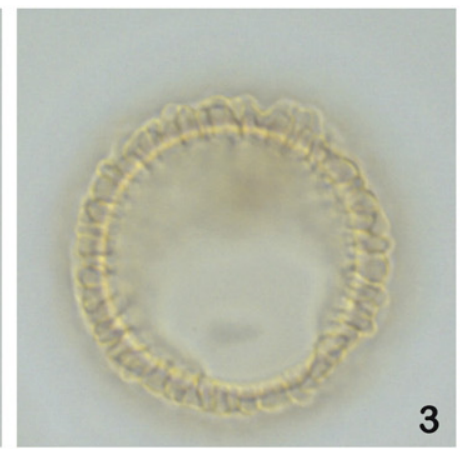

3

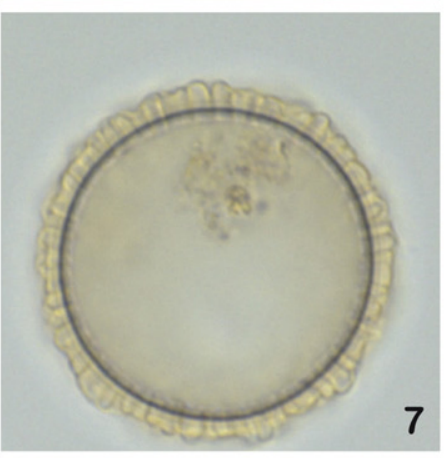

7
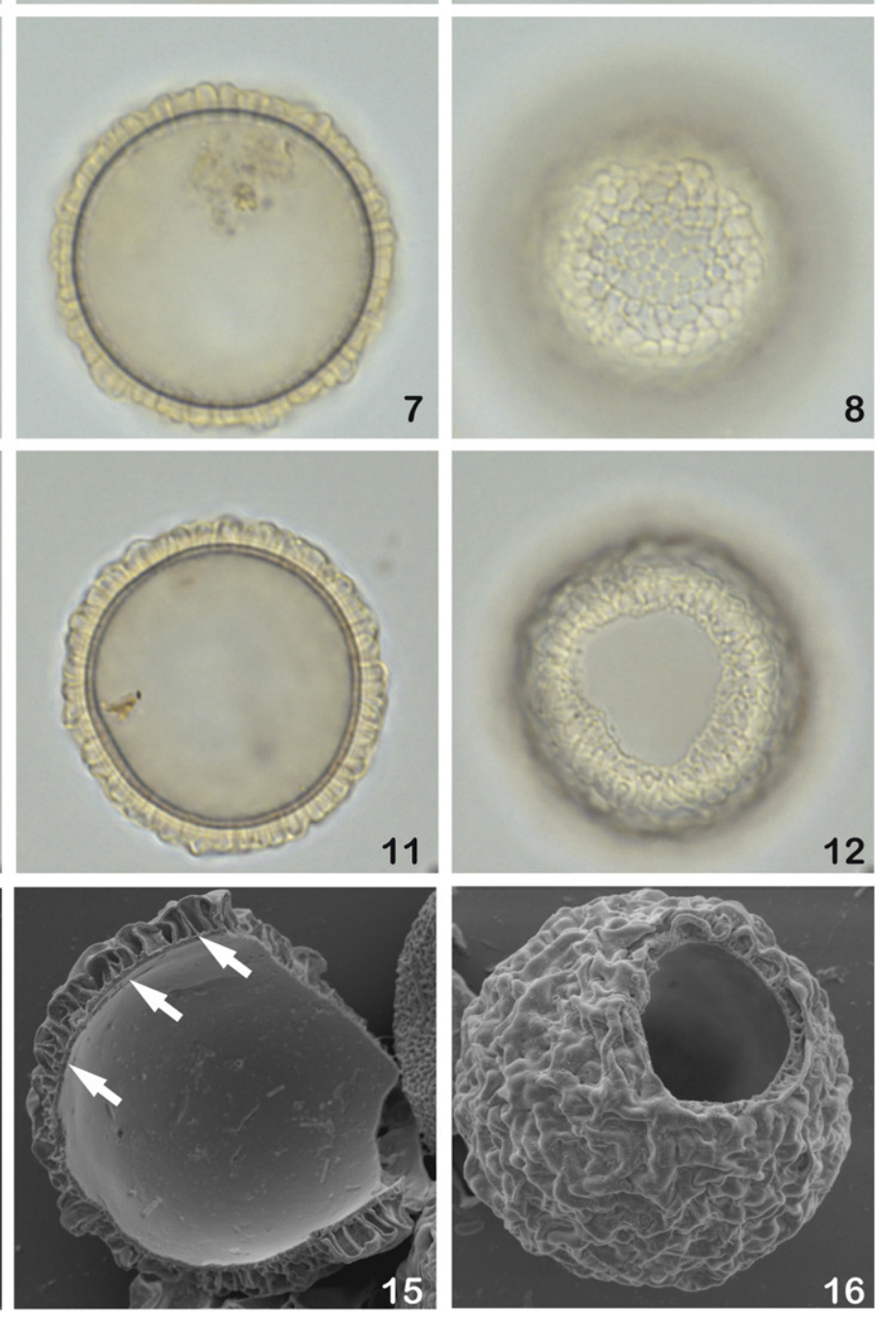

Plate I. Batiacasphaera bergenensis sp. nov. All images are in bright field illumination (1-12) or SEM (13-16). Various magnifications. EF = England Finder reference.

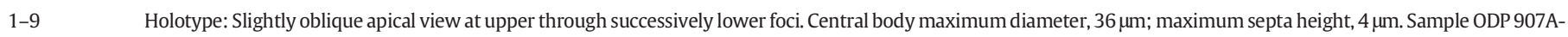
19H-1, 34-36 cm, slide 1; EF: P42/2. 1-4, upper and slightly lower foci illustrating the apical archeopyle. Note the low angularity and lack of accessory sutures. 4-7, Different mid-foci illustrating wall differentiation into pedium and luxuria. Note the variation in septa height and irregular outline of cyst in equatorial view. 8-9, subsequently lower foci showing irregular nature of surface ornamentation.

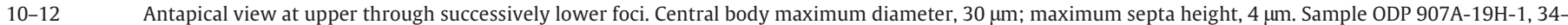
$36 \mathrm{~cm}$, slide 1; EF: R50/0. 10, Antapical view at high focus illustrating the microreticulate appearance of surface ornament under light microscope due to 'LO' effect. 11, Antapical view in mid-focus showing a solid pedium. Note the irregular outline of cyst caused by variation in septa height. 12 , Antapical view in low focus showing the apical archeopyle.

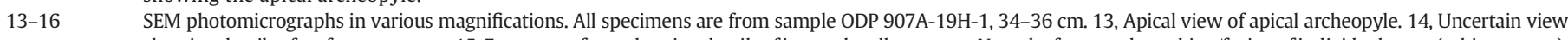
showing details of surface ornament. 15, Fragment of cyst showing details of internal wall structure. Note the frequent branching/fusing of individual septa (white arrows). 16 , Oblique apical view on archeopyle.

Batiacasphaera bergenensis sp. nov. (Plate I, 1-16)

2013 Filisphaera sp. A, Schreck et al.
Holotype: Sample ODP 907A-19H-1, 34-36 cm; slide 1; England Finder reference P42/2; Plate I, 1-9. 
Repository: Invertebrate Section of the Department of Palaeobiology, Royal Ontario Museum, Toronto, Ontario, Canada; catalogue number ROM 63053.

Type locality: ODP Site 907 , eastern Iceland Plateau $\left(69^{\circ} 14.989^{\prime} \mathrm{N}\right.$, $\left.12^{\circ} 41.894^{\prime} \mathrm{W}\right)$.

Stratigraphic horizon: ODP Hole 907A, $169.10 \mathrm{mbsf}$; lower Serravallian (upper Middle Miocene), Subchron C5ABn, calibrated age $13.39 \mathrm{Ma}$.

Etymology: Named after the Norwegian city of Bergen, where the apical archeopyle of this species has first been observed.

Diagnosis: A species of Batiacasphaera having a spherical central body, thin solid inner wall layer and thicker outer wall of non-tabular irregular high (up to $5 \mu \mathrm{m}$ ), narrow solid septa which form a continuous tectum of closely adjoining blisters with polygonal to elongate outline. Archeopyle apical, and operculum free, other tabular features absent. Description: Small to medium sized holocavate proximate cyst with a spherical central body, but undulating outline in cross-section (Plate I, 4,5 and 11). The cyst wall consists of two layers; a thin $(<1 \mu \mathrm{m})$ pedium that appears solid under light microscope, and a luxuria, which comprises non-tabular, distributed solid septa of uneven height (c. 2-5 $\mu \mathrm{m}$ on individual specimens) that expand distally to create a tectum in the form of numerous closely adjoining blisters. Cysts are rarely crumpled or folded due to the thick wall. Where they branch distally, septa are indented, and sometimes slightly thickened as seen under light microscope. Larger specimens usually have higher septa (Fig. 5), and variation of septa height occurring on the same cyst and indentation at intersections account for the undulating outline of the central body in optical section. Under SEM, individual septa may additionally branch and/or fuse at random height over entire length (Plate I, 15). Spacing between septa varies on individual specimens. The variations in septa height and spacing result in a continuous but irregular tectum comprising densely spaced blisters. The shape of blisters is irregular rounded polygonal to rectangular, sometimes elongated with significant variations in size (Plate I, 9 and 14), and they may appear as a reticulum under light microscope due to 'LO' effect (Plate I, 8 and 9). The distribution pattern of blisters does not reflect any tabulation pattern. This ornament spreads over the entire surface of the cyst without variation, and extends to the archeopyle margins without modification. The archeopyle is apical with a low to moderately angular principal suture that appears slightly thickened (Plate I, 1,12 and 16), and lacks accessory sutures. The shape of the archeopyle indicates that it is presumably formed by loss of 3 apical plates. The operculum is free

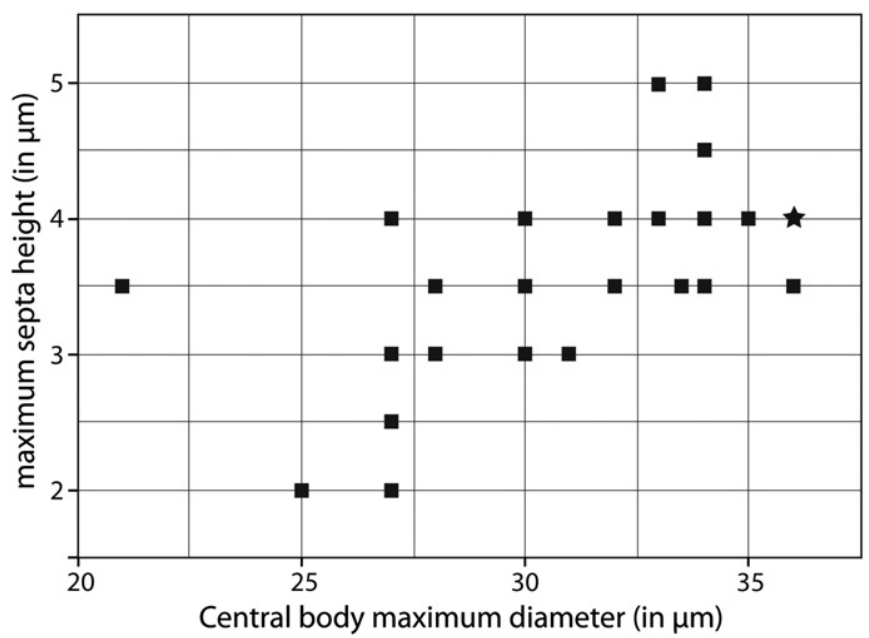

Fig. 5. Central body maximum diameter vs. maximum septa height for Batiacasphaera bergenensis sp. nov. Black star $=$ holotype and was not observed on any specimen. There is no other expression of tabulation.

Discussion: This species has been assigned to the genus Batiacasphaera due to its spherical central body, low surface ornament, and apical archeopyle presumably consisting of 3 apical plates. It possesses a slightly thickened principal archeopyle suture, which is typical for some Batiacasphaera species. It differs from all other Batiacasphaera species in having a cyst wall composed of a thin pedium that supports a luxuria of solid, high septa which form a tectum rather than two closely appressed wall layers as typical for the genus. In Kallosphaeridium de Coninck 1969 the multiplate apical archeopyle is attached to the sulcus. Blysmatodinium argoi McMinn, 1992 differs in having a type tA apical archeopyle, and being thin walled. In addition, the blisters of $B$. argoi are broadly spaced rather than closely adjoined and show evidence of alignment parallel to the cingulum. Batiacasphaera bergenensis sp. nov. differs from Habibacysta tectata Head et al., 1989b in having an apical archeopyle, and septa rather than columellae. Filisphaera filifera Bujak 1984, which has a similar internal wall structure, has a precingulur archeopyle and shorter septa that form a microreticulum instead of blisters.

Dimensions: Holotype: Central body maximum diameter (without luxuria), $36 \mu \mathrm{m}$, maximum septa height, $4 \mu \mathrm{m}$. Range: Central body maximum diameter (without luxuria), 21(30.6)36 $\mu \mathrm{m}$, maximum septa height, 2(3.5)5 $\mu \mathrm{m}$. Thirty-five specimens were measured (see also Fig. 5).

Stratigraphic occurrence: In Iceland Sea ODP Hole 907A, Batiacasphaera bergenensis sp. nov. ranges from the uppermost Langhian (13.68 Ma) through lower Tortonian (11.09 Ma). There is no other record of this species to date.

Group ACRITARCHA Evitt, 1963

Genus LAVRADOSPHAERA De Schepper and Head, 2008

Type Lavradosphaera crista De Schepper and Head, 2008

Lavradosphaera elongata sp. nov. (Plate II, 1-16)

?1989 Dinocyst 7, Manum et al., Pl. 8, 10-11.

2013 ?Lavradosphaera sp. 1, Schreck et al., Pl. I, 9-12.

Holotype: Sample ODP 907A-23H-6, 97.5-99.5 cm; slide 1; England Finder reference 048/3; Plate II, I-4.

Repository: Invertebrate Section of the Department of Palaeobiology, Royal Ontario Museum, Toronto, Ontario; catalogue number ROM 63054.

Type locality: ODP Site 907, eastern Iceland Plateau $\left(69^{\circ} 14.989^{\prime} \mathrm{N}\right.$, $12^{\circ} 41.894^{\prime} \mathrm{W}$ )

Stratigraphic horizon: ODP Hole 907A, 215.30 mbsf; mid-Langhian (lower Middle Miocene); calibrated age 14.33 Ma.

Etymology: Named with reference to the characteristic elongate shape of the central body of this species.

Diagnosis: A thick-walled species of Lavradosphaera with an elongated central body bearing irregular crests, ridges or cones. Operculum simple and free.

Description: A mid-sized acritarch with an elongate to ovoidalellipsoidal central body. The wall consists of a thin basal layer, a finely cancellous middle layer of varying thickness, and a finely ornamented thin outer layer. All layers are closely appressed over entire vesicle. The cancellous middle layer varies in thickness across the entire central body, and is partly raised to form an irregular relief of incomplete crests, ridges and cones. These vary in height (usually up to $1 / 3$ of the entire wall height), width, and length, but all are wider at the base and narrow distally. Their distribution and density vary over the entire vesicle. Largest crests may have rectangular to polygonal contours forming distinctive elevated platforms under light microscope (Plate II, 1, 6, 7 and 16). Inner and outer walls are both thin $(<0.5 \mu \mathrm{m})$ and solid. The surface ornament of the outer wall layer is smooth to scrabrate, and may be covered by a dense network of perforations (Plate II, 6). These perforations are unevenly distributed and may be absent on elevated areas 


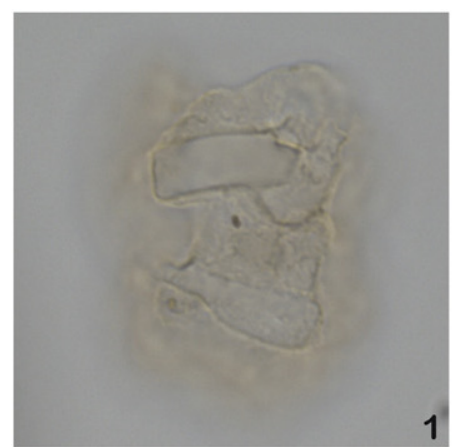

1

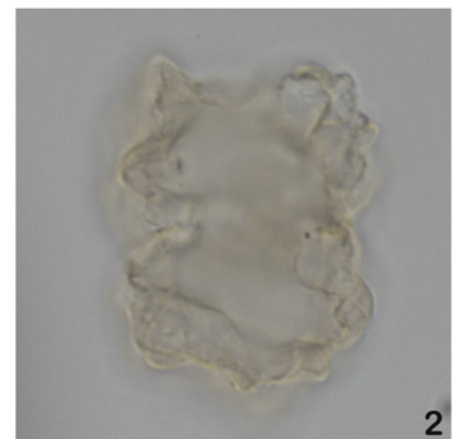

5

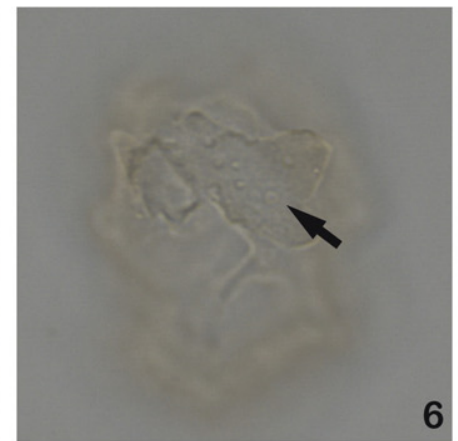

6

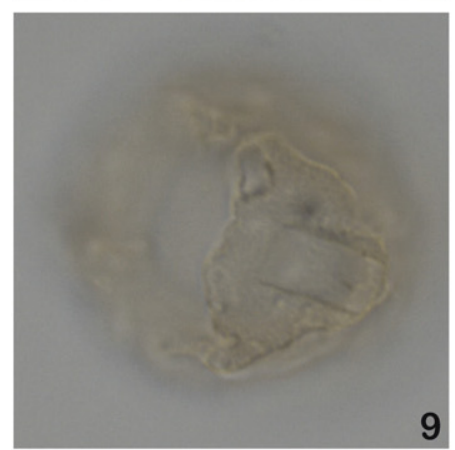

9

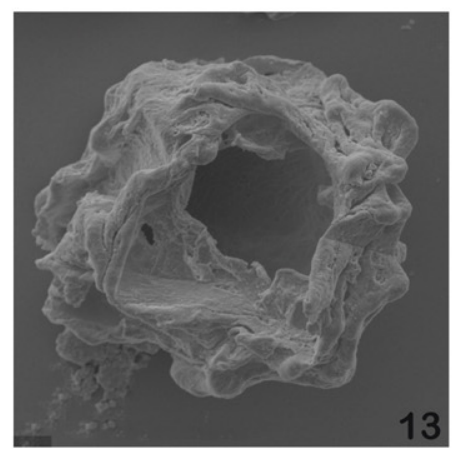

2

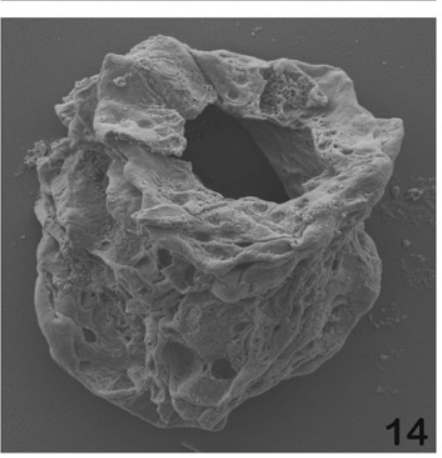

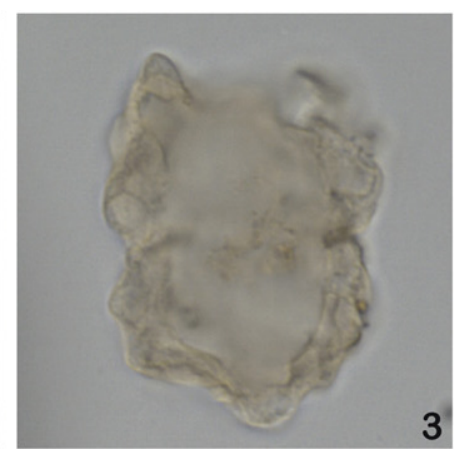

3

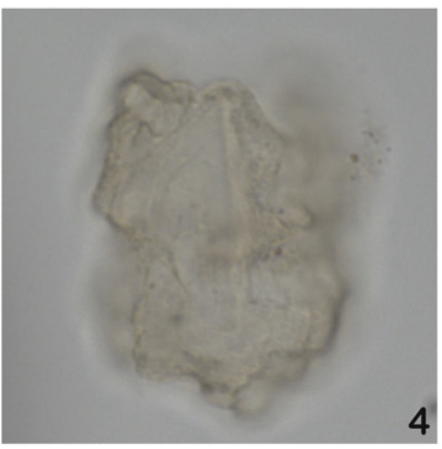

7
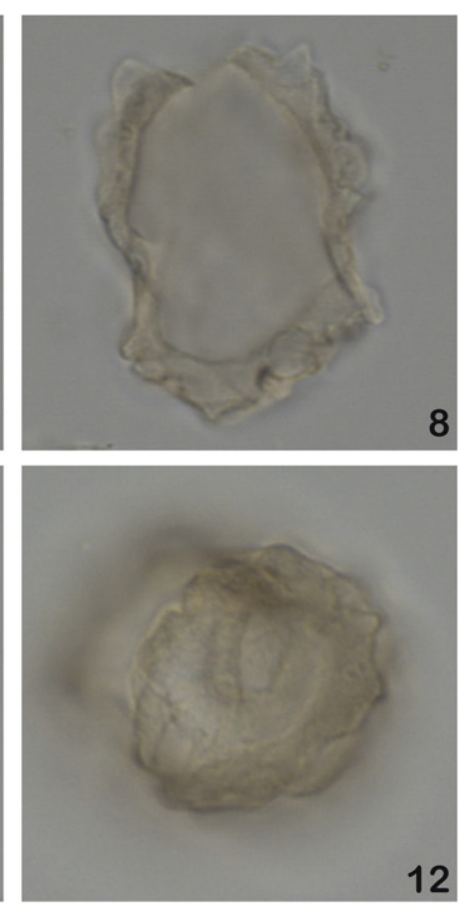

11
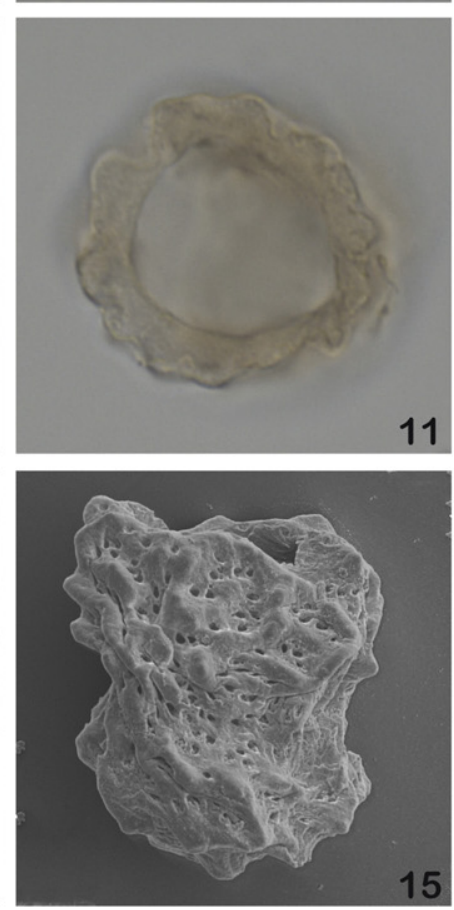

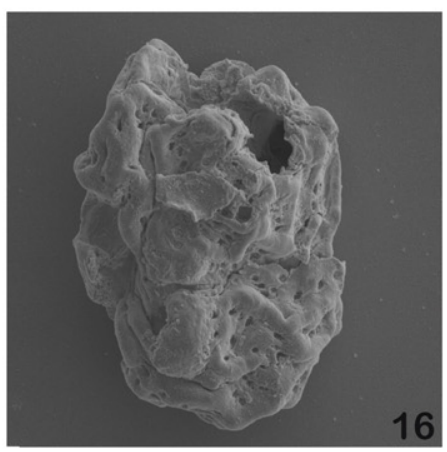

Plate II. Lavradosphaera elongata sp. nov. All images are in bright field illumination (1-12) or SEM (13-16). Various magnifications. EF = England Finder reference.

Holotype. Uncertain lateral view at upper through lower foci. Maximum length, $32 \mu \mathrm{m}$; maximum width, $24 \mu \mathrm{m}$. Sample ODP 907A-23H-6, 97.5-99.5 cm, slide 1; EF = 048/ 3. 1, Upper focus illustrating the typical rectangular structures on the surface, and 2, slightly lower focus. 3, Mid-focus illustrating the elongate outline and undulating outer wall. 4, Low focus.

$5 \quad$ Uncertain lateral view at low focus showing details of the apical margin.

Maximum length, $32 \mu \mathrm{m}$; maximum width, $25 \mu \mathrm{m}$. Sample ODP 907A-23H-6, 97.5-99.5 cm, slide 1; EF = Q42/4.

$6-8$

Uncertain lateral view. Maximum length, $35 \mu \mathrm{m}$; maximum width, $23 \mu \mathrm{m}$. Sample ODP 907A-23H-6, 97.5-99.5 cr

ing scattered, unevenly distributed perforations (black arrow), and 7, successively lower focus, 8, mid-focus.

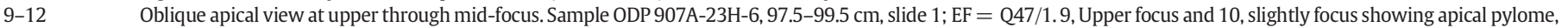
11 , mid-focus illustrating the thick and undulating wall in optical section. 12, Low focus.

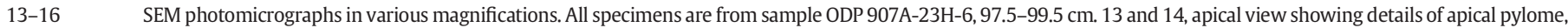
and pylome margin. 15 and 16, illustrating the elongate outline and details of the perforated wall surface. Note the irregular distribution of perforations.

(Plate II, 15, 16). They vary in diameter (usually $<1 \mu \mathrm{m}$ ), and are rounded to polygonal in outline under SEM. Pylome is rounded to polygonal with low angles, and the principle suture is slightly thickened (Plate II, 5, 9, 13 and 14). The margins of the pylome are inclined towards the centre and undulating (Plate II, 14). The operculum is free, and has not been observed.

Discussion: This species has been assigned to the genus Lavradosphaera due to its cancellous middle and thin outer wall layer that form crests, 
ridges or cones. However, Lavradosphaera elongata sp. nov. differs from all other described species of Lavradosphaera in having a more elongated central body. In addition, it differs from Lavradosphaera crista in having a continuously thick wall bearing irregular distributed ridges, crests and cones, and from Lavradosphaera lucifer in lacking the acute points typical for that species. Lavradosphaera canalis and Lavradosphaera cf. L. canalis both differ in having a smooth surface deeply incised by U- to rounded V-shaped channels. There is no stratigraphic overlap with any other described species of the genus.

Dimensions: Holotype: Maximum length (including wall), $32 \mu \mathrm{m}$, maximum width (including wall), $24 \mu \mathrm{m}$. Range: Maximum length (including wall), 29(36)40 $\mu \mathrm{m}$, maximum width (including wall), 21(27.8)29 $\mu \mathrm{m}$. Twenty-one specimens measured.

Stratigraphic occurrence: Lavradosphaera elongata sp. nov. is common to abundant throughout the Middle Miocene of Hole 907A and ranges continuously from the base of the hole in the mid-Langhian (c. $14.5 \mathrm{Ma}$ ) to its HO in the upper Serravallian (11.81 Ma, upper Middle Miocene) close to the Middle to Late Miocene boundary. The upper stratigraphic range of dinocyst 7 of Manum et al. (1989), which we tentatively synonymise with L. elongata sp. nov., is also confined to the Middle Miocene in ODP Hole 643A from the Vøring Plateau, where it has a HO close to the Langhian/Serravallian boundary (Manum et al., 1989; Goll unpubl. data in Williams and Manum, 1999).

\section{Concluding remarks}

The two proposed species, the dinocyst Batiacasphaera bergenensis sp. nov and the acritarch Lavradosphaera elongata sp. nov., have distinct morphologies that are easily recognizable under light microscope. Their well-defined range tops have been magnetostratigraphically-calibrated to the upper Serravallian and lowermost Tortonian of Iceland Sea ODP Site 907 respectively. Both appear to be potentially useful regional biostratigraphic marker within an interval of eminent relevance to unravel the Neogene history of the Greenland ice sheet. Their occurrence at ODP Site 907 furthermore suggests that both species presumably have an affinity for warm-temperate waters or at least sensitivity against cooler surface waters. However, detailed future analyses of this interval at other locations in the Norwegian-Greenland Sea will have to further confirm the age ranges given, as well as the tentative assessment of paleoecological preferences.

\section{Acknowledgements}

The Ocean Drilling Project provided samples used within this study. We thank Walter Hale and Alex Wülbers for technical support while sampling at the IODP Core Repository (Bremen), and Ute Böck for technical support in the SEM facility at AWI-Bremerhaven. Discussions with Stijn De Schepper (University of Bergen) and Martin J. Head (Brock University) were greatly welcomed, and the helpful comments of two anonymous reviewers are appreciated. We acknowledge the German Research Foundation (DFG) for financial support (DFG MA 3913/2), and MS is additionally grateful to funding by the K-Polar project (No. PP13030) and the Basic Research Program (No. PE14062), both supported by the Korea Polar Research Institute.

\section{References}

Amigo, A.E., 1999. Miocene silicoflagellate stratigraphy: Iceland and Rockall Plateaus. In: Raymo, M.E., Jansen, E., Blum, P., Herbert, T.D. (Eds.), Proceedings of the Ocean Drilling ProgramScientific Results 162. College Station, TX, pp. 63-81.

Blindheim, J.,Østerhus, S., 2005. The Nordic Seas, main oceanographic features. In: Drange, H., Dokken, T., Furevik, T., Gerdes, R., Berger, W. (Eds.), The Nordic Seas - An integrated perspective. American Geophysical Union, Washington, DC, pp. 11-38.

Bujak, J.P., Matsuoka, K., 1986. Late Cenozoic dinoflagellate cyst zonation in the western and northern Pacific. Contributions Series 17American Association of Stratigraphic Palynologists, Dallas, TX, pp. 7-25.

Channell, J.E.T.,Amigo, A.E., Fronval, T., Rack, F., Lehman, B., 1999. Magnetic stratigraphy at Sites 907 and 985 in the Norwegian-Greenland Sea and a revision of the Site 907 composite section. In: Raymo, M.E., Jansen, E., Blum, P., Herbert, T.D. (Eds.),
Proceedings of the Ocean Drilling ProgramScientific Results 162. College Station, TX, pp. 131-148.

De Schepper, S., Head, M.J., 2013. New Pliocene and Pleistocene acritarchs: correlation potential in high latitude oceans. J. Syst. Palaeontol. http://dx.doi.org/10.1080/ 14772019.2013 .783883$.

De Schepper, S., Fischer, E.I., Groeneveld, J., Head, M.J., Matthiessen, J., 2011. Deciphering the palaeoecology of Late Pliocene and Early Pleistocene dinoflagellate cysts. Palaeogeogr. Palaeoclimatol. Palaeoecol. 309, 17-32.

DeConto, R.M., Pollard, D., Wilson, P.A., Paelike, H., Lear, C.H., Pagani, M., 2008. Thresholds for Cenozoic bipolar glaciation. Nature 455, 652-656.

Denk, T., Grímsson, F., Zetter, R., Símonarson, L.A., 2011. Late Cenozoic floras of Iceland 15 million years of vegetation and climate history in the northern North Atlantic. Springer, Heidelberg, $854 \mathrm{pp}$

Fensome, R.A.,Crux, J.A.,Gard, G.I.,MacRae, R.A.,Williams, G.L., Thomas, F.C.,Fiorini, F.,Wach, G. 2008. The last 100 million years on the Scotian Margin, offshore eastern Canada: an event-stratigraphic scheme emphasizing biostratigraphic data. Atl. Geol. 44, 93-126.

Flower, B.P.,Kennett, J.P., 1994. The middle Miocene climatic transition: East Antarctic ice sheet development, deep ocean circulation and global carbon cycling. Palaeogeogr. Palaeoclimatol. Palaeoecol. 108, 537-555.

Fronval, T., Jansen, E., 1996. Late Neogene paleoclimates and paleoceanography in the Iceland-Norwegian Sea: evidence from the Iceland and Vøring Plateaus. In: Thiede, J., Myhre, A.M., Firth, J.V., Johnson, G.L., Ruddiman, W.F. (Eds.), Proceedings of the Ocean Drilling ProgramScientific Results 151. College Station, TX, pp. 455-468.

Head, M.J., Norris, G., Mudie, P., 1989a. Palynology and dinocyst stratigraphy of the Miocene in ODP Leg 105, Hole 645E, Baffin Bay. In: Srivastava, S.P., Arthur, M., Clement, B. (Eds.), Proceedings of the Ocean Drilling ProgramScientific Results 105. College Station, TX, pp. 467-514.

Head, M.J., Norris, G., Mudie, P., 1989b. New species of dinocysts and a new species of acritarch from the upper Miocene and lowermost Pliocene, ODP Leg 105, Site 646, Labrador Sea. In: Srivastava, S.P., Arthur, M., Clement, B. (Eds.), Proceedings of the Ocean Drilling ProgramScientific Results 105. College Station, TX, pp. 453-466.

Helland, P.E.,Holmes, M.A., 1997. Surface textural analysis of quartz sand grains from ODP Site 918 off the southeast coast of Greenland suggests glaciation of southern Greenland at 11 Ma. Palaeogeogr. Palaeoclimatol. Palaeoecol. 135, 109-121.

Hilgen, F.J., Lourens, L.J., Van Dam, J.A., 2012. The Neogene period. In: Gradstein, F., Ogg, J., Schmitz, M., Ogg, G. (Eds.), The Geological Time Scale 2012. Elsevier, Amsterdam, pp. 923-978.

Jakobsson, M., Backman, J., Rudels, B., Nycander, J., Frank, M., Mayer, L., Jokat, W.,Sangiorgi, F., O'Regan, M., Brinkhuis, H., King, J., Moran, K., 2007. The early Miocene onset of a ventilated circulation regime in the Arctic Ocean. Nature 447, 986-990.

Knies, J.,Gaina, C., 2008. Middle Miocene ice sheet expansion in the Arctic: views from the Barents Sea. Geochem. Geophys. Geosyst. 9 Q02015.

Manum, S.B., Boulter, M.C., Gunnarsdottir, H., Rangnes, K., Scholze, A., 1989. Eocene to Miocene Palynology of the Norwegian Sea (ODP Leg 104). In: Eldholm, O., Thiede, J. , Taylor, E. (Eds.), Proceedings of the Ocean Drilling ProgramScientific Results 104. College Station, TX, pp. 611-662.

Matthiessen, J., Brinkhuis, H., Poulsen, N.E.,Smelror, M., 2009a. Decahedrella martinheadii Manum 1997 - a stratigraphically and paleoenvironmentally useful Miocene acritarch of the northern high latitudes. Micropaleontology 55, 171-186.

Matthiessen, J.. Knies, J., Vogt, C., Stein, R., 2009b. Pliocene palaeoceanography of the Arctic Ocean and subarctic seas. Phil. Trans. R. Soc. A 367, 21-48 (The Royal Society, London).

McMinn, A., 1992. Neogene dinoflagellate distribution in the eastern Indian Ocean from Leg 123, Site 765. In: Gradstein, F.M., Ludden, J.N. (Eds.), Proceedings of the Ocean Drilling ProgramScientific Results 123. College Station, TX, pp. 429-441.

Mudie, P., 1989. Palynology and dinocyst biostratigraphy of the Late Miocene to Pleistocene, Norwegian Sea: ODP Leg 104, Sites 642 to 644. In: Eldholm, O., Thiede, J., Taylor, E. (Eds.), Proceedings of the Ocean Drilling ProgramScientific Results 104. College Station, TX, pp. 587-610.

Party, Shipboard Scientific, 1995. Site 907. In: Myhre, A.M., Thiede, J., Firth, J.V. (Eds.), Proceedings of the Ocean Drilling ProgramInitial Reports 151. College Station, TX, pp. $57-111$.

Poulsen, N.E., Manum, S.B., Williams, G.L., Ellegaard, M., 1996. Tertiary dinoflagellate biostratigraphy of Sites 907, 908, and 909 in the Norwegian-Greenland Sea. In: Thiede, J., Myhre, A.M., Firth, J.V., Johnson, G.L., Ruddiman, W.F. (Eds.), Proceedings of the Ocean Drilling ProgramScientific Results 151. College Station, TX, pp. 255-287.

Sarnthein, M., Bartoli, G., Prange, M.,Schmittner, A.,Schneider, B., Weinelt, M., Andersen, N., Garbe-Schönberg, D., 2009. Mid-Pliocene shifts in ocean overturning circulation and the onset of Quaternary-style climates. Clim. Past 5, 269-283.

Schaeffer, R., Spiegler, D., 1986. Neogene Kälteeinbrüche und Vereisungsphasen im Nordatlantik. Z. Dtsch. Geol. Ges. 137, 537-552.

Schreck, M., Matthiessen, J., 2013. Batiacasphaera micropapillata: Palaeobiogeographic distribution and palaecological implications of a critical Neogene species complex. In: Lewis, J., Marret, F., Bradley, L. (Eds.), Biological and geological perspectives of dinoflagellatesThe Micropalaeontological Society, Special Publications. Geological Society, London, pp. 301-314.

Schreck, M., Matthiessen, J., Head, M.J., 2012. A magnetostratigraphic calibration of Middle Miocene through Pliocene dinoflagellate cyst and acritarch events in the Iceland Sea (Ocean Drilling Program Hole 907A). Rev. Palaeobot. Palynol. 187, 66-94.

Schreck, M.,Meheust, M.,Stein, R., Matthiessen, J., 2013. Response of marine palynomorphs to Neogene climate cooling in the Iceland Sea (ODP Hole 907A). Mar. Micropaleontol. $101,49-67$.

Serreze, M.C., Barry, R.G., 2011. Processes and impacts of Arctic amplification: a research synthesis. Glob. Planet. Chang. 77, 85-96.

Thiede, J.,Jessen, C.,Knutz, P.,Kuijpers, A.,Mikkelsen, N.,Nørgaard-Pedersen, N.,Spielhagen, R., 2011. Millions of years of Greenland ice sheet history recorded in ocean sediments. Polarforschung 80, 141-159. 
Verhoeven, K., Louwye, S., Paez-Reyes, M., Mertens, K., Vercauteren, D., 2013. New acritarchs from the late Cenozoic of the southern North Sea Basin and the North Atlantic realm. Palynology, http://dx.doi.org/10.1080/01916122.2013.793626.

Westerhold, T.,Bickert, T.,Röhl, U., 2005. Middle to Late Miocene oxygen isotope stratigraphy of ODP Site 1085 (SE Atlantic): new constrains on Miocene climate variability and sea-level fluctuations. Palaeogeogr. Palaeoclimatol. Palaeoecol. 217, 205-222.

Williams, G.L., Manum, S.B., 1999. Oligocene-Early Miocene dinocyst stratigraphy of Hole 985A (Norwegian Sea). In: Raymo, M.E., Jansen, E., Blum, P., Herbert, T.D. (Eds.), Proceedings of the Ocean Drilling ProgramScientific Results 162. College Station, TX, pp. 99-109.

Wolf-Welling, T.C.W.,Cremer, M.,O'Connell, S.,Winkler, A.,Thiede, J., 1996. Cenozoic Arctic gateway paleoclimate variability: indications from changes in coarse-fraction composition. In: Thiede, J., Myhre, A.M., Firth, J.V., Johnson, G.L., Ruddiman, W.F. (Eds.), Proceedings of the Ocean Drilling Program, Scientific Results 151. College Station, TX, pp. 515-567.

Wood, G.D., Gabriel, A.M., Lawson, J.C., 1996. Palynological techniques - processing and microscopy. In: Jansonius, J., McGregor, D.C. (Eds.), Palynology: Principles and ApplicationVolume 1 Principles. American Association of Stratigraphic Palynologists Foundation, Dallas, TX, pp. 29-50.

Zachos, J.C., Dickens, G.R.,Zeebe, R.E., 2008. An early Cenozoic perspective on greenhouse warming and carbon-cycle dynamics. Nature 451, 279-283. 